\title{
Bromelain and Amylase Assisted Extraction of Cucurbita pepo Seed Oil Enriched with Phytosterol
}

\section{Nguyen Thi Minh Tu${ }^{1 *}$, Kieu Thi Hoang Yen ${ }^{1}$, Tran Huong Nga ${ }^{1}$, Le Tat Thanh $^{2}$ and Dang Thi Thu ${ }^{1}$}

${ }^{1}$ School of Biotechnology and Food Technology, Hanoi University of Science and Technology, Vietnam

${ }^{2}$ Institute of Natural Products Chemistry, Vietnam Academic of Science and Technology, Vietnam

*Corresponding Author: Nguyen Thi Minh Tu, School of Biotechnology and Food Technology, Hanoi University of Science and Technology, Vietnam.
Received: September 22, 2020

Published: October 28, 2020

(C) All rights are reserved by Nguyen Thi Minh Tu., et al.

\section{Abstract}

Pumpkin (Cucurbita pepo) seeds' hydrolysis condition was investigated in order to achieve oil containing high content of phytosterol by using enzyme bromelain and amylase. For this purpose, hydrolysis conditions of bromelain and amylase including ratio of $C$. pepo to water, ratio of concentration of the enzyme bromelain/amylase to substance, temperature, $\mathrm{pH}$, hydrolysis time were investigated.

Bromelain hydrolysis of $C$. pepo seeds with $1.75 \%$ enzyme at $55^{\circ} \mathrm{C}$ for $7 \mathrm{hrs}$ at $\mathrm{pH}$ of 7 gave $27.83 \%$ oil and $1909.95 \mathrm{mg}$ phytosterol in $100 \mathrm{~g}$ oil. For amylase hydrolysis these figures were $0.9 \% ; 50^{\circ} \mathrm{C} ; 5.5 \mathrm{hrs}$ and 7 , respectively; and the oil yield was $14.02 \%$ with $2245.03 \mathrm{mg}$ phytosterol in $100 \mathrm{~g}$ oil.

Although oil yield by using enzyme bromelain (27.83\%) and enzyme amylase (14.02\%) was lower than that by using solvent and ultrasonic methods (26.57\% to $42.74 \%$ ), phytosterol content inversely was as 2 to 3 times as higher (631.41 - 772.78 to 19909.95 $2245.03 \mathrm{mg} / 100 \mathrm{~g}$ oil). Fourteen compounds were found in phytosterol mixture obtained by amylase hydrolysis, among them three important e.g. campesterol, stigmasterol, $\beta$ - sitosterol accounted for 315.460, 120.111 and $189.987 \mathrm{mg} / 100 \mathrm{~g}$ oil respectively.

Keywords: Amylase; Bromelain; Oil of Pumpkin Seed; Phytosterol

\section{Introduction}

According to FAO statistics, pumpkin area worldwide was more 2.04 million hectares, and the yield reached $13,531 \mathrm{~kg} / \mathrm{ha}$ in 2018. This data was 444,679 ha in China, 99,510 ha in Turkey and 580,244 ha in India, while those yields were 18,411; 6,192 and $9,599 \mathrm{~kg} / \mathrm{ha}$, respectively [1]. In Vietnam, pumpkins are spread across the country because of their high adaptability. Although no specific figures are avaiable, pumpkin production is considered to be potential in agriculture of Vietnam [2].

Phytosterol is one of the most important composition of pumpkin seed with high value biology. Phytosterol content is different from pumpkin seed sources such as $265 \mathrm{mg} / 100 \mathrm{~g}$ for Cucurbita spp. (United States) in 2005 [3]; 190 - 320 mg/100g oil for C.pepo convar citrullina (Serbia) in a study of N. Hrabovski., et al. in 2012 [4]; $317.2 \mathrm{mg} / 100 \mathrm{~g}$ oil for C. pepo which reported by Nederal-Nakic'., et al. in 2006 [5]. Phytosterol has been used in many enriched functional foods, which is first appeared about twenty years ago and many clinical studies have confirmed its LDL cholesterol- lowing properties [6-8]. There are some products enriched in plant sterols/stanols such as yogurts, milk, spreads and margarines and their beneficial effects have been claimed in clinical studies of Gylling., et al. 2014 [9]. Nutritionists have recognized two classes of 
phytosterols, there are plant sterols and plant stanols. Plant sterols have a double bond in the sterol ring and the most abundant phytosterols for the human diet are $\beta$-sitosterol, campesterol and stigmasterol. The other, plant stanols lack a double bond in the sterol ring, especially sitostanol and campestanol, which comprise only about $10 \%$ of total dietary phytosterols [10-12]. Foods or beverages contain at least $1.7 \mathrm{~g}$ plant sterols, when consumed twice a day for total intake of $3.4 \mathrm{~g}$ per day help lowering saturated fat and cholesterol and reducing the risk of coronary heart disease (FDA health claim) $[13,14]$.

Soxhlet extraction using traditional solvents such as hexane, petroleum ether or ultrasonic assisted or Bligh and Dyer yielded oil higher than that of conventional leaching [15]. However, the use of solvents has limitations in terms of safety and environmental harms. Therefore, using of biological methods (enzymes), assisting the oil enriched in phytosterol extraction from pumpkin is of interest and application.

Unlike the chemical solvent method, the enzyme method uses water as a special solvent to release compounds out from the mmembrane thanks to the enzyme's hydrolyzation. Due to the hydrophobic properties of oil in water, after enzyme treatment, oil is mechanically separated [16]. Bromelain and Amylase are two common enzymes for cleaving starch and protein in sequence. Using them for hydrolysis helps cleavage the bonds of starch and proteins in the structure of the grain, releasing oil bags. Previously, Kosar Zakeril and partners has found the optimal condition of the hydrolysis process using enzyme Alcalase with E/S = 3\%, temperature $44^{\circ} \mathrm{C}$ for 40 minutes resulted in increasing antioxidant activity of pumpkin seed oil [18].

\section{Aim of the Study}

The aim of this study was to use amylase and bromelain for pumpkin seeds treatment to increase phytosterol's content in the obtained oil, which can alternatively replace methods using a solvent.

\section{Material and Methods}

\section{Material}

Pumpkin seeds (Cucurbita pepo) of Vietnam were harvested in the autumn of 2019 , dried to a storage humidity of $34.9 \%$.

Bromelain and amylase were purchased from Bio Green -Vietnam and Novo- Denmark, respectively and their specifications are presented in table 1.

\begin{tabular}{|l|c|c|}
\hline Specifications & Bromelain & Amylase \\
\hline Activity (IU/g) & 1200 & 1300 \\
\hline $\mathrm{pH}$ & $6-8$ & $5-9$ \\
\hline Temperature $\left({ }^{\circ} \mathrm{C}\right)$ & $40-60$ & $40-80$ \\
\hline Substrate & Protein & Starch \\
\hline
\end{tabular}

Table 1: Specifications of bromelain (Bio Green -Vietnam) and amylase (Novo- Denmark).

\section{Methods}

\section{Solvent extraction}

Soxhlet extraction: $5 \mathrm{~g}$ of pumpkin seeds blended for 1 - $2 \mathrm{~mm}$ was subjected to Soxhlet extraction using hexane solvent at 55 $60^{\circ} \mathrm{C}$ for 7 hours [19].

Bligh and dyer extraction: $100 \mathrm{~g}$ of pumpkin seeds were blended for $1-2 \mathrm{~mm}$, then $200 \mathrm{ml} \mathrm{MeOH}$ and $100 \mathrm{ml} \mathrm{CHCl}_{3}(\mathrm{v} / \mathrm{v}=$ $2 / 1$ ) were added. Ultrasound assisted this extraction for 2 hours, at $37 \mathrm{KHz}$. Then, solid phase was subjected to second extraction using $100 \mathrm{ml} \mathrm{CHCl}_{3}$, ultrasonic assisting for 1 hour. The liquid phases of 2 extractions were combined, the lipid phase was isolated by liquid-liquid extraction, total lipid was obtained after evaporation [20].

Ultrasound assisted solvent extraction:100 grams of ground pumpkin seeds with $300 \mathrm{ml}$ hexane solvent was performed in triplicate under ultrasonic waves of $37 \mathrm{Khz}$. Liquid phases were combined and the solvent was evaporated to obtain lipid extraction.

\section{Enzyme assisted extraction}

Pumpkin seed/water ratio, enzyme/substrate ratio, temperature, $\mathrm{pH}$ and hydrolysis time were investigated at $1 / 7$ to $1 / 11 ; 1$ to $2 \%$ at $0,25 \%$ jump; 6 to 8 at 0,5 jump; 40 to $60^{\circ} \mathrm{C}$ at $5^{\circ} \mathrm{C}$ jump; 4 to 8 hours, at 1 hour jump, respectively for bromelain; while those were: $1 / 5$ to $1 / 9 ; 0.7$ to $1.1 \%$ at $0.1 \%$ jump; 5 to 8 at 1 jump; 40 to $80^{\circ} \mathrm{C}$ at $10{ }^{\circ} \mathrm{C}$ jump; 4 to 6 hours at 0.5 hour jump, respectively for amylase.

The activity of enzyme bromelain and amylase is expressed by dissolved protein content and by reducing sugar content, respectively.

At the end of enzymatic hydrolysis, oil-enriched phytosterol was obtained by centrifugation at $7000 \mathrm{rpm}$ for 5 minutes. 
Total protein content analysis

Total protein content was determined by Bradford assay, which relies on the binding of the dye Coomassie Blue G250 to protein. The result is achieved by measuring the absorbance of the solution at $595 \mathrm{~nm}$ and comparing with standard curve using the formula: [21]

$y=\frac{x-0.2238}{0.2237}$

Where: x: Optical adsorption (OD) at $595 \mathrm{~nm}$.

y: Protein concentration of sample $(\mathrm{mg} / \mathrm{ml})$.

Total reducing sugar content analysis

DNS (Dinitrosalicylic acid) is one of the reagents used to estimate reducing sugars in the solution. 3,5- Dinitrosalicylic acid is reduced to 3 amino 5 nitro salicylic acid while oxidizing the reducing sugars. The color change can be quantified spectrophotometrically at a wavelength of $540 \mathrm{~nm}$ and the total sugar content is determined by the followings [22]:

$y=\frac{x-0.3883}{0.0443}$

Where: x: Optical adsorption (OD) at $540 \mathrm{~nm}$.

y: Reducing sugar concentration of sample $(\mu \mathrm{g} / \mathrm{ml})$.

Total lipid content analysis: The lipid content was analyzed by the Soxhlet method [19].

\section{Total phytosterols content analysis}

Blended pumpkin seeds after 1extraction, $1 \mathrm{ml}$ lipid phase was collected by centrifugation at $7000 \mathrm{rpm}$ then evaporated. Phytosterol content was determined equivalent to $\beta$-sitosterol by ultraviolet-visible spectrophotometer.

$\mathrm{y}=C s * \mathrm{Aa} / \mathrm{As} * n * 100$

Where:

$\mathrm{C}_{\mathrm{s}}$ : Standard concentration

$A_{a}$ : Absorbance of the sample; $A_{s}=$ Absorbance of the standard

y: Reducing sugar concentration of sample $(\mu \mathrm{g} / \mathrm{ml})$

n: Dilute coefficient of sample

100: Coefficient for $100 \mathrm{ml}$ oil pumpkin seed extraction..

\section{Phytosterol composition}

Pumpkin seed oil obtained by amylase assisted extraction was treated with the ratio of $\mathrm{KOH} 5 \%$ to oil of 2,6 ; at $74^{\circ} \mathrm{C}$ for $4 \mathrm{hrs}$ for phytosterol enrichment. Then the sample was transformed into a derivative of trimethylsilyl (TMS) at $70^{\circ} \mathrm{C}$ for 2 hours. The extract with n-hexane was evaporated then analysed on gas chromatograph Thermo Finnigan Italia S.P.A. TRACE GC Ultra series, equipped with DB column $30 \mathrm{~m} \times 0.53 \mathrm{~mm}$, film $0.5 \mu \mathrm{m}$, the program ran from $200^{\circ} \mathrm{C}, 2^{\circ} \mathrm{C} / \mathrm{min}$, to $300^{\circ} \mathrm{C}$ then kept for 10 minutes, carrier gas, flow rate $10 \mathrm{ml} /$ minute. The phytosterols will be compared with previously run standards to identify each ingredient and quantify with the calibration curve of each substance.

\section{Results and Discussion}

Cucurbita pepo's seed composition

Cucurbita pepo seed's composition is presented in table 2. Oil content was of $42.74 \%$ which was of the same range with $C$. pepo from Serbia and higher than that of C. maxima of Bangladesh. Phytosterol content was $2705.76 \mathrm{mg} / 100 \mathrm{~g}$ oil, much higher than that was found in Serbia sample. Protein (36.42\%) and starch (10.08\%) accounted for $81.15 \%$ of non-oil content of pumpkin seed, therefore, using bromelain and amylase for hydrolysis helps cleavage the bonds of starch and proteins in the structure of the pumpkin to release oil and phytosterol more effectively.

\begin{tabular}{|l|c|c|c|}
\hline & $\begin{array}{c}\text { Cucur- } \\
\text { bita pepo, } \\
\text { Vietnam }\end{array}$ & $\begin{array}{c}\text { Cucurbita } \\
\text { pepo, } \\
\text { Serbia [4] }\end{array}$ & $\begin{array}{c}\text { Cucurbita } \\
\text { maxima, Ban- } \\
\text { gladesh [23] }\end{array}$ \\
\hline Moisture (\%) & 8.02 & 9.20 & 4.06 \\
\hline Ash (\%) & 4.28 & - & 3.80 \\
\hline Total protein (\%) & 36.42 & - & 2.15 \\
\hline Sugar (\%) & 10.08 & - & \\
\hline Starch (\%) & 9.07 & - & 34.56 \\
\hline Total oil (\%) & 42.74 & 43.37 & 36.70 \\
\hline
\end{tabular}

Table 2: Pumpkin seed composition.

Cucurbita pepo's seed treatment with bromelain and amylase was investigated in term of seed to water ratio, enzyme to seed ratio, $\mathrm{pH}$, temperature, and time. The results were expressed in protein $(\mathrm{mg} / \mu \mathrm{g})$ for bromelain or reducing sugar $(\mathrm{mg} / \mu \mathrm{g})$ for amylase treatment (Figure 1). 

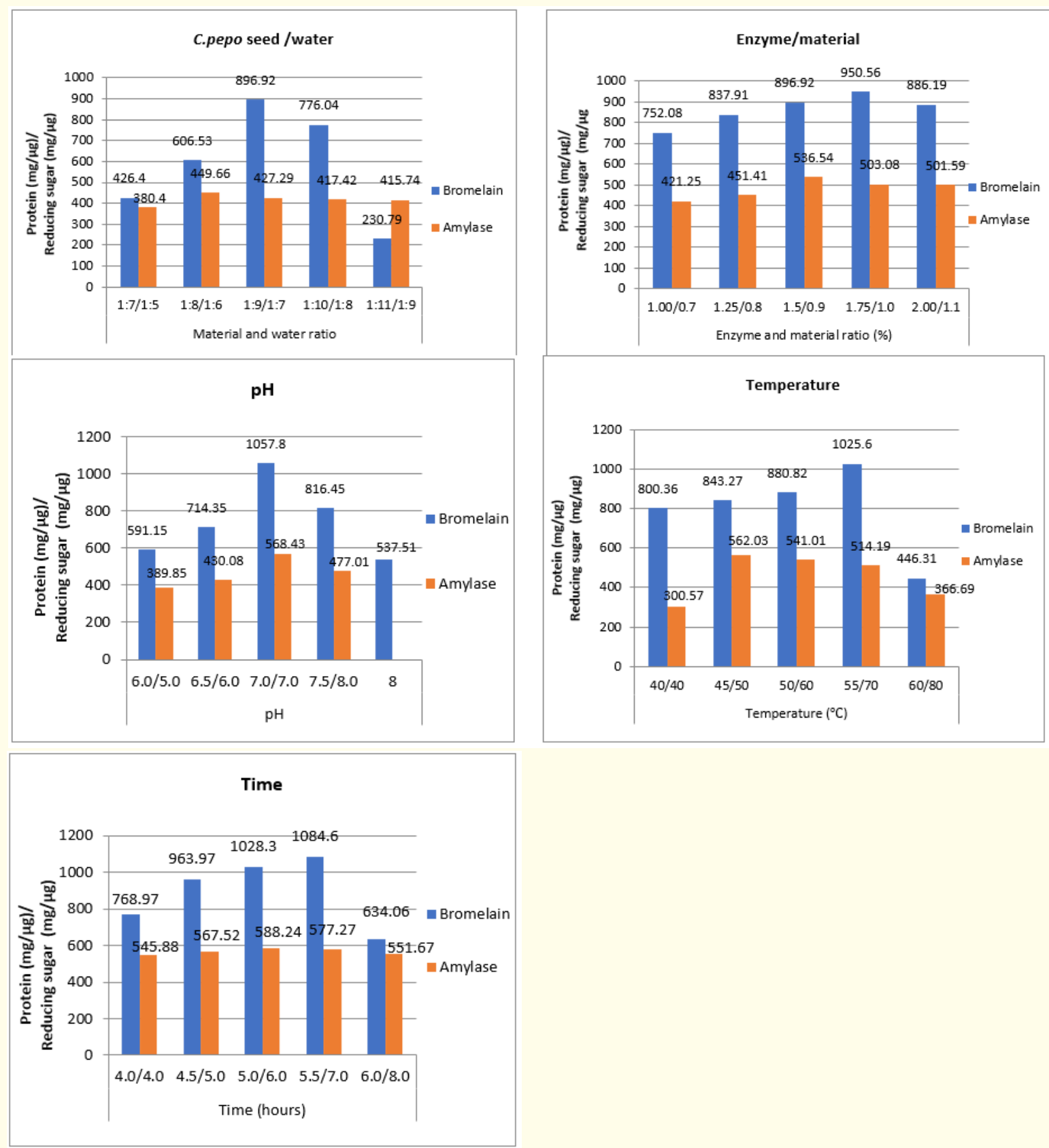

Figure 1: Cucurbita pepo seeds treatment by bromelain and amylase.

In the enzymatic hydrolysis, water was added at an appropriate ratio for enzyme activation, while temperature influenced on the diffusion rate and viscosity reduction. Results are figured out in figure 1 , in which the suitable condition for $C$. pepo seeds treatment by bromelain were: $C$. pepo seed/water $=1 / 9$, bromelain/ material $=1.75 \%$, at $55^{\circ} \mathrm{C}, \mathrm{pH}=7$ for 7 hours. At this treatment the protein released highest at $1025.66 \mathrm{mg}$ at $55^{\circ} \mathrm{C}$ before reducing to $446.31 \mathrm{mg}$ when hydrolysis temperature was $60^{\circ} \mathrm{C}$. For amylase, those were: $C$. pepo seed/water $=1 / 6$, amylase $/$ material $=0.9 \%$, at $50^{\circ} \mathrm{C}, \mathrm{pH}=7$ for 5.5 hours and reducing sugar content released as highest as $588.24 \mu \mathrm{g}$. 
Hexane extraction, bligh and dyer extraction, ultrasound assisted hexane extraction, enzyme assisted extraction

The performance of hexane extraction $\left(55-60^{\circ} \mathrm{C}\right.$, in 6 hours); Bligh and Dyer extraction $\left(\mathrm{CH}_{2} \mathrm{Cl}_{2} / \mathrm{MeOH}(2 / 1)\right.$ at $45-50^{\circ} \mathrm{C}$, in 3 hours); ultrasound assisted hexane extraction (ultrasonic waves of $37 \mathrm{Khz}$, at $45-50^{\circ} \mathrm{C}$, in 3 hours); enzyme assisted extraction (With bromelain: $C$. pepo seed $/$ water $=1 / 9$, enzyme $/$ material $=1.75 \%$, at $55^{\circ} \mathrm{C}, \mathrm{pH}=7$, in 7 hours and with amylase: $C$. pepo seed/water $=1 / 6$, enzyme $/$ material $=0.9 \%$, at $50^{\circ} \mathrm{C}, \mathrm{pH}=7$, in 5.5 hours) is presented in table 3 in term of oil recovery (\%), oil yield (g/100g material), phytosterol content (mg/100 ml oil).

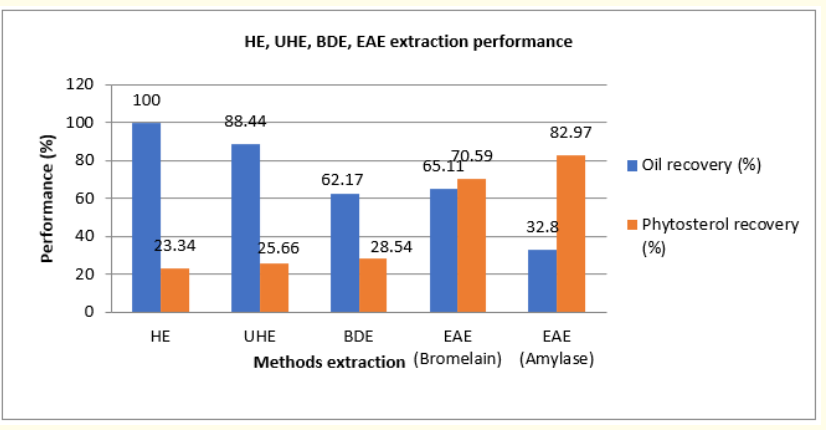

Figure 2: Oil and phytosterol extraction performance.

\begin{tabular}{|c|c|c|c|c|c|}
\hline \multirow{2}{*}{ Extraction performance } & \multirow{2}{*}{ HE } & \multirow{2}{*}{ UHE } & \multirow{2}{*}{ BDE } & \multicolumn{2}{|c|}{ EAE } \\
\hline & & & & Bromelain & Amylase \\
\hline Oil recovery (\%) & 100 & 88.44 & 62.17 & 65.11 & 32.80 \\
\hline Oil yield (g/100g material) & 42.74 & 31.62 & 26.57 & 27.83 & 14.02 \\
\hline Phytosterol content (mg/100 ml oil) & $631.41 \pm 2.88$ & $694.24 \pm 2.53$ & $772.78 \pm 3.65$ & $1909.95 \pm 3.34$ & $2245.03 \pm 3.52$ \\
\hline
\end{tabular}

Table 3: HE, UHE, BDE, EAE extraction performance.

HE: Hexane Extraction; UHE: Ultrasound Assisted Hexane Extraction; BDE: Bligh and Dyer Extraction; EAE: Enzyme Assisted Extraction.

Oil recovery is highest in hexane extraction. Phytosterol yield (mg/100g material) were 269.84; 219.52; 205.31; 531.54 and 314.75 for HE, UHE, BDE, bromelain EAE and amylase EAE, respectively. Phytosterol (mg/100g oil) in pumpkin seed (C. pepo convar citrullina) oil extracted by hexane, petroleum ether and supercritical $\mathrm{CO}_{2}$ claimed by Natasa Hrabovski and partners 2012 [20] were in the same range of 225,244 and 294, respectively. The difference in phytosterol extraction could be explained with difference in extraction kinetics of phytosterol and triglycerides in plant cell structure. Using enzymes, the sterols and stanols are extracted more easily and effectively. Thus, the phytosterol content (mg/100 ml oil) were $631.41 ; 694.24 ; 772.78 ; 1909.95$ and 2245.03 for HE, UHE, BDE, bromelain_EAE and amylase_EAE, respectively. Among bromelain and amylase, amylase assisted extraction gave less oil yield but better in phytosterol enrichment.

\section{Phytosterol composition}

The composition of Phytosterol is presented in the table 4 .

\begin{tabular}{|l|c|c|}
\hline Phytosterol & $\begin{array}{c}\text { Content } \\
\text { (mg/100g } \\
\text { pumpkin seed } \\
\text { oil) }\end{array}$ & $\begin{array}{c}\text { Reference } \\
\text { (mg/100g } \\
\text { pumpkin seed } \\
\text { oil) [17] }\end{array}$ \\
\hline Cholesterol & 20.796 & 9.21 \\
\hline Brassicasterol & 42.466 & 11.32 \\
\hline 24-Methylenecholesterol & 34.635 & 9.30 \\
\hline Campesterol & 315.46 & 82.46 \\
\hline Campestanol & 36.335 & 8.08 \\
\hline Stigmasterol & 120.111 & 97.71 \\
\hline$\triangle^{7}$-Camersterol & 36.114 & 32.44 \\
\hline$\triangle^{5,23}$ Stigmastadienol & 24.446 & 21.57 \\
\hline Chlerosterol & 720.325 & 525.91 \\
\hline$\beta$ - Sitosterol & 189.987 & 264.25 \\
\hline Sitostanol & 111.422 & 112.67 \\
\hline$\triangle^{5}$-Avenasterol & 76.356 & 15.92 \\
\hline$\triangle^{5,24}$-Stigmastadienol & 455.678 & 394.18 \\
\hline$\triangle^{7}$-Avenastenol & 76.222 & 34.09 \\
\hline Total Phytosterol & 2260.353 & 1619.55 \\
\hline
\end{tabular}

Table 4: The composition of phytosterol. 
Three important compositions of phytosterol e.g. campesterol, stigmasterol, $\beta$ - sitosterol accounted for 315.460, 120.111 and $189.987 \mathrm{mg} / 100 \mathrm{~g}$ oil respectively.

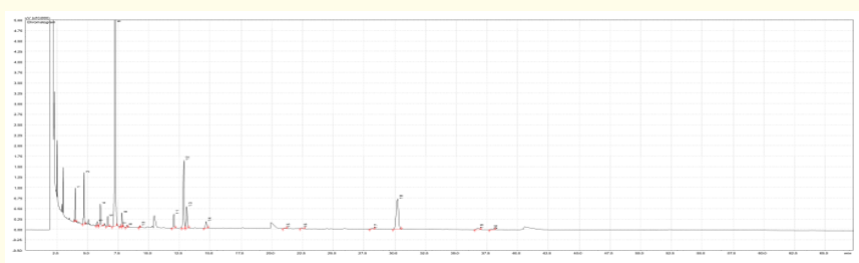

Figure 3: Chromatogram of phytosterol on DB-5 column.

\section{Conclusion}

Bromelain assisted extraction at $55^{\circ} \mathrm{C}, \mathrm{pH}=7$, for 7 hours with $C$. pepo seed $/$ water $=1 / 9$, Enzyme $/$ material $=1.75 \%$ yielded phytosterol concentration in oil of $1909.95 \mathrm{mg} / 100 \mathrm{ml}$ oil, while amylase assisted extraction at $50^{\circ} \mathrm{C}, \mathrm{pH}=7$, for 5.5 hours with $C$. pepo seed/ water $=1 / 6$, Enzyme $/$ material $=0.9 \%$, yielded phytosterol concentration in oil of $2245.03 \mathrm{mg} / 100 \mathrm{ml}$ oil. Hexane, Bligh and Dyer extraction and ultrasonic assisted hexane extraction were carried out for comparison, and their phytosterol content in $100 \mathrm{ml}$ oil were about 3 times lower than that performed by enzyme assisted extraction. Bromelain and amylase assisted extraction improved the phytosterol concentration in the oil obtained, where amylase gave less oil yield but better in phytosterol enrichment. The oil yield of this method is lower than that of solvent and ultrasonic extraction, therefore, C. pepo seed after enzyme extraction is recommended for second solvent extraction to obtain more oil. The extracted phytosterol consisted of 14 components in which campesterol, stigmasterol, $\beta$ - sitosterol accounted for 315.460, 120.111 and 189.987 $\mathrm{mg} / 100 \mathrm{~g}$ oil respectively.

\section{Acknowledgment}

This research was supported by grants from the Ministry of Education and Training of Viet Nam (B2019-BKA-07).

\section{Bibliography}

1. FAO (Food and Agriculture Organization). "Pumpkins, squash and gourds". (2018).

2. LT Phong., et al. "Pumpkin production: potential and challenges". Journal of Vietnam Agriculture Science and Technology 2 (2011): 46-50.
3. KM Phillips., et al. "Phytosterol composition of nuts and seed commonly consumed in the United States". Journal of Agricultural and Food Chemistry 53.24 (2005): 9436-9445.

4. N Hrabovski., et al. "Phytosterols in pumpkin seed oil extracted by organic solvents and supercritical C02". European Journal of Lipid Science and Technology 114 (2012): 1024-1211.

5. N Nakic., et al. "Chemical characteristics of oils from naked and husk seeds of Cucurbita pepo L". European Journal of Lipid Science and Technology 108.11 (2006): 936-943.

6. P Laakso. "Analysis of sterols from various food matrices". European Journal of Lipid Science and Technology 107.6 (2015): 402-410.

7. J Quílez., et al. "Potential uses and benefits of phytosterols in diet: present situation and future directions". Clinical Nutrition 22.4 (2003): 343-351.

8. CE Cabral and M RST Klein. "Phytosterols in the Treatment of Hypercholesterolemia and Prevention of Cardiovascular Diseases". Journal of Brazilian society of Cardiology 109.5 (2017): $475-482$.

9. H Gylling., et al. "Plant sterols and plant stanols in the management of dyslipidaemia and prevention of cardiovascular disease". Atherosclerosis 232.2 (2014): 346-360.

10. R Moreau., et al. "Phytosterols and their derivatives: Structural diversity, distribution, metabolism, analysis, and health-promoting uses". Progress in Lipid Research 70 (2018): 35-61.

11. D Heimburger and A Jamy. "Handbook of Clinical Nutrition". $4^{\text {th }}$ Edition (2006): 422-447.

12. MA Alfawaz. "Chemical composition and Oil Characteristics of Pumpkin (Cucurbita maxima) Seed Kernels". Food Sci and Agric. Res. Center, King Saud Univ 129 (2004): 5-18.

13. T S Cynthia and A H Ermias. "Quanitification of plant sterols/ stanols in foods and dietary supplements containing added phytosterol". Journal of Food Composition and Analysis 40 (2015): 163-176.

14. FDA (Food and Drug Administration). "Health claims: plant sterol/ stanol essters and risk of coronary heart disease (CHD)". CFR. Title 21.2 (2019).

15. MJ Lagarda., et al. "Analysis of phytosterols in food". Journal of Pharmaceutical and Biomedical Analysis 41 (2006): 14861496. 
16. Munger M Linda., et al. "Enzymatic hydrolysis of steryl glycosides for their analysis in foods". Food Chemistry 163 (2014): 202-211.

17. LTL Thuy. "Research and develop technological process for producing oil from pumpkin seeds by enzyme method". Ho Chi Minh City, Vietnam 7318 (2008).

18. K Zakeri., et al. "Optimization of Hydrolysis Condition of Pumpkin Seeds with Alcalase Enzyme to Achieve Maximum Antioxidant and Nitric Oxide Inhibition Activity Kosar". Journal of Research and Innovation in Food Science and Technology 7 (2018): 445-458.

19. H. D. Tu and partners, Phân tích hóa học thực phẩm, $3^{\text {rd }}$ Edition, Publishing Scientific and Technical, Hanoi, Vietnam (2009).

20. EG Bligh and WJ Dyer. "A rapid method for total lipid extraction and purification". Canadian Journal of Biochemistry and Physiology 37 (1959): 911-917.

21. Bradford and MM. "A rapid and sensitive method for the quantitation of microgram quantities of protein utilizing the principle of protein-dye binding". Analytical Biochemistry 72 (1976): 248-254.

22. GL Miller. "Use of Dinitrosalicylic Acid Reagent for Determination of Reducing Sugar". Analysis Chemistry 31 (1959): 426428.

23. Habib S., et al. "Nutritional and Lipid Composition Analysis of Pumpkin Seed (Cucurbita maxima Linn)". Journal of Nutrition and Food Science 5.4 (2015).

\section{Assets from publication with us}

- Prompt Acknowledgement after receiving the article

- Thorough Double blinded peer review

- Rapid Publication

- Issue of Publication Certificate

- High visibility of your Published work

Website: www.actascientific.com/

Submit Article: www.actascientific.com/submission.php

Email us: editor@actascientific.com

Contact us: +919182824667

Citation: Nguyen Thi Minh Tu., et al. "Bromelain and Amylase Assisted Extraction of Cucurbita pepo Seed Oil Enriched with Phytosterol". Acta Scientific Nutritional Health 4.11 (2020): 50-56. 